\title{
Post-secular Expertise and American Foreign Policy
}

The past two decades, following the end of the Cold War and the events of 9/11, witnessed a growing interest in religion among American scholars and policy analysis that touches upon the broad field of international affairs. ${ }^{1}$ This interest is not only confined to the field of international affairs, but is a much wider phenomenon that cuts across disparate fields and disciplines - from philosophy, to the humanities, the natural sciences, and medicine - so much so, that John Schmalzbauer and Kathleen Mahoney, have talked about an increasingly "post-secular academy." 2 This post-secular turn in the academy, Schmalzbauer and Mahoney argue, has been spearheaded by a "religious resurgence movement," a heterogeneous and often uncoordinated group of scholars, who have both directly and indirectly "raised the profile of religion in American higher education."3

A similar movement has taken place in the field of international affairs, with the rise of what I call American post-secular expertise on international affairs. The concept of post-secular here does not define who these experts are - whether they are religious or not, or whether they used to be secular in the private and public sphere and now religious - but what they do. That is, these experts are post-secular because they are closely tied to the production of a particular knowledge regime that seeks to challenge the dominant secular paradigms that underpin the social sciences as well as international affairs scholarship.

This article argues that much American scholarship challenging the secular premises of social scientific research on international affairs cannot be completely divorced from parallel efforts directed towards challenging the secular premises of American foreign policy. In other words, American scholarship seeking to bring a better understanding of religion into the social scientific study of international affairs is in many cases either explicitly or implicitly contributing -

1 I use the term "international affairs" to include a broad range of fields and disciplines, such as international relations, comparative politics, peace and security studies, area studies, international law, and/or international and comparative sociology.

2 John Schmalzbauer and Kathleen Mahoney, "Religion and Knowledge in the Post-Secular Academy” (New York: SSRC Working Papers, 2012). See also John Schmalzbauer and Kathleen A. Mahoney, “American Scholars Return to Studying Religion,” Contexts 7.1 (2008).

3 Schmalzbauer and Mahoney, "Religion and Knowledge in the Post-Secular Academy," 24. 
to paraphrase Schmalzbauer and Mahoney - to raising the profile of religion in American foreign policy.

We can think of post-secular expertise and experts as constituting a particular kind of epistemic community. An epistemic community is "a network of professionals with recognized expertise and competence in a particular domain and an authoritative claim to policy-relevant knowledge within that domain or issue area." ${ }^{4}$ Post-secular experts base much of their authority on their social scientific knowledge of religion(s), as well as - in many cases - on their firsthand religious belief, belonging, and experience. ${ }^{5}$ These experts are challenging social scientists and policymakers alike to recognize and acknowledge the importance of religion as a social phenomenon, and, when speaking also from a religious perspective, as a way of knowing. ${ }^{6}$ Thinking of American post-secular experts not simply as detached scholars, but also as taking part in a epistemic community - a heterogeneous and pluralist one with its internal debates, disagreements and often competing agendas - conceptually highlights their relationship and relevance to policy debates and policy-making. ${ }^{7}$

The post-secular epistemic community on international affairs is influential in American foreign policy debates and practices in three ways. First, it has been effective in discursively arguing that religion matters in world politics. In particular, it has highlighted the limits of standard secularization theories and secular knowledge paradigms, showing that religions are not only still alive and well in the modern world, but also that their social and political salience is globally resurging.

Second, this epistemic community has been important in arguing not only that religion matters, but also in showing how it matters. In particular, it has challenged the premises of much social scientific research that understands religion exclusively as epiphenomenal and reducible to other factors - whether economic, political, or individual. It has put forward the case for treating religion, instead, as "an independent variable" or as an "autonomous force." A

4 Peter M. Haas, “Introduction: Epistemic Communities and International Policy Coordination,” International Organization 46.1 (1992): 3.

5 I will use interchangeably the terms expertise, experts, and epistemic community. For a discussion about religious actors and organizations, not including scholars, as an "epistemic community," see Nukhet A. Sandal, "Religious Actors as Epistemic Communities in Conflict Transformation: The Cases of South Africa and Northern Ireland," Review of International Studies 37.3 (2011).

6 Some, for instance, have a triple orientation - as committed religious individuals, as scholarly analysts of religion, and as policy-engaged actors on matters of religion.

7 Gil Eyal and Larissa Buchholz, "From the Sociology of Intellectuals to the Sociology of Interventions,” Annual Review of Sociology 36 (2010): 129. 
growing number of international events, especially when it comes to conflict and violence or peace and democracy, cannot be understood if one does not take religion - whether actors, communities, beliefs, or identities - seriously into account, these authors claim.

Third, drawing from the above arguments, post-secular experts have often concluded that American foreign policy cannot afford to ignore a world that is experiencing a revival in the social and political salience of religions. The point is made that, if America is to create a more peaceful and secure international order, its diplomats and security officials need to shed much of their secular biases and do a better job in understanding religion and including religious actors and resources in foreign policy. Hence, we often find that scholars and centers engaged in the social scientific study of religion and its effects on international societies and politics are also engaged in debates on two key issues which pertain to American foreign policy: religious engagement and faithbased approaches to conflict-resolution, and the promotion of international religious freedom.

An investigation into the connections between post-secular expertise and American foreign policy is warranted for a number of reasons. First, because there has been little research carried out so far on this relationship and what it means for the pursuit of social scientific knowledge about religion beyond the United States. The intent here is not to get involved in normative and policy debates about the necessity, or perils, of bringing religion into American foreign policy. Nor do I want to make any specific claims about the need for or impossibility of having a more clear distinction between objective, value-neutral social scientific research on religion, and subjective normative religious preferences and ethics. Furthermore, it is not my intention to engage in contentious debates about First Amendment interpretations regarding the establishment clause and the free exercise of religion when it comes to American foreign policy.

The point is, however, to generate a more self-reflective debate within the social scientific study of religion about the American-centric nature of much of this literature - not only in terms of its origins in the American academy, but also because of its substantial proximity to America's national interest and foreign policy concerns. Put differently, the scope here is not to engage in policy debates, or to critique or praise post-secular expertise, nor to police the boundaries of what appropriate scholarship on religion should be. The intent here is largely of a sociological and analytical nature: to highlight and make more explicit, as others have done in other domains, ${ }^{8}$ a phenomenon that has generally

8 For example, the heavy American footprint in terms of scholars, institutions, funding, and 
been underappreciated and overlooked when it comes to scholarship on religion in international affairs.

Second, this investigation is warranted because scholarly research on the influence of religion in American foreign policy, so far, has generally ignored the place and role of elites and post-secular expertise. In fact, while interest in religion and American foreign policy has grown exponentially over the past decade, most of the literature has focused on the role of religious organizations and movements, ${ }^{9}$ or on the personal religiosity of American people ${ }^{10}$ and their presidents, ${ }^{11}$ or on the religious - protestant and missionary - character of American exceptionalism and national identity. ${ }^{12}$ Yet, that experts and epistemic communities can and do have an influence on foreign policy has been shown by an increasing number of studies, ${ }^{13}$ none of which, however, has paid enough attention to post-secular expertise.

To be specific, this chapter does not offer any strictly causal or explanatory analysis. I will not trace the process nor identify the precise mechanisms through which the American post-secular epistemic community on international affairs has affected American foreign policy. Its scope is more modest. On the one hand, it maps the emergence of post-secular expertise on international affairs. It traces two novel phenomena. First, the development of new policy-oriented centers and initiatives in key universities, think tanks, and research institutes dedicated to the study of religion. Second, it traces the development of important

what type of research is being produced, and for what purposes, in international relations (IR) the discipline I identify with - has long been recognized in the field itself. See Stanley Hoffmann, “An American Social Science: International Relations,” Daedalus 106.3 (1977); Ole Waever, "The Sociology of a Not So International Discipline: American and European Developments in International Relations," International Organization 52. 04 (1998).

9 See, among many, Stephen R. Rock, Faith and Foreign Policy: The Views and Influence of U.S. Christians and Christian Organizations (New York, NY: Continuum International, 2011).

10 See, among many, James L. Guth, "Religion and American Public Opinion: Foreign Policy Issues," The Oxford Handbook of Religion and American Politics, ed. James L. Guth, Lyman A. Kellstedt, and Corwin E. Smidt (New York/Oxford: Oxford University Press, 2009); Walter Russell Mead, “God's Country,” Foreign Affairs 85.5 (2006).

11 See, among many, Andrew Bacevich and Elizabeth Prodromou, "God Is Not Neutral: Religion and US Foreign Policy after 9/11,” Orbis 48.1 (2004).

12 Dennis R. Hoover, ed. Religion and American Exceptionalism (New York, NY: Routledge, 2014).

13 Emanuel Adler and Peter M. Haas, “Conclusion: Epistemic Communities, World Order, and the Creation of a Reflective Research Program,” International Organization 46.1 (1992); Jeffrey T. Checkel, "Ideas, Institutions, and the Gorbachev Foreign Policy Revolution," World Politics 45.2 (1993); Jolyon Howorth, "Discourse, Ideas, and Epistemic Communities in European Security and Defence Policy,” West European Politics 27. 2 (2004). 
faith-based think and do tanks, which have contributed substantially to the rise of religion in scholarly and policy debates. On the other hand, this mapping is used to highlight the connections between academic and official narratives, and the institutional links between key individuals and centers constitutive of the post-secular epistemic community, and the religious engagement and international religious freedom foreign policy agendas.

Third, and lastly, the neglect of research on post-secular expertise appears also rooted in a general portrayal of American elites as singularly secular, whether individually secularized (with little believing in or belonging to any religion), epistemically secular (with no interest in the study of religion), or ideologically secularist (with anti-religious sentiments). Such an understanding of the secular nature of American intellectual life is put forward, among many, by important American sociologists of religion, such as Peter Berger and Christian Smith. ${ }^{14}$ This chapter contributes to challenging this dominant narrative of intellectual and scholarly elites, in general, and American ones, in particular, as overwhelmingly secular, secularized, and secularist.

The essay is organized around two main sections that follow each other in chronological order. The first section charts the early emergence of the post-secular epistemic community from the end of the Cold War up to around the year 2000. The second section traces the expansion of post-secular expertise in the American academy and among policy-oriented research institutions following the events of 9/11. These two sections highlight how post-secular expertise consolidated around a number of key themes as they became ever more important in the making and delivery of American foreign policy from the $1990 \mathrm{~s}$ onwards, namely: producing better knowledge and understanding of religion, engaging religious communities abroad to resolve conflicts, promoting international religious freedom norms and arrangements.

\section{1989-2000: The Emergence of Post-secular Expertise}

With the end of the Cold War, debates in Washington DC about the Soviet threat, containment, balance of power, and mutually assured destruction increasingly

14 Peter L. Berger, ed. The Desecularization of the World: Resurgent Religion and World Politics (Grand Rapids, MI: Ethics and Public Policy Center; Eermans Publishing, 1999); Christian Smith, The Secular Revolution: Power, Interests, and Conflict in the Secularization of American Public Life (London: University of California Press, 2003). 
petered out. The American foreign policy establishment was left in search of new paradigms and perspectives that would help interpret and explain the emerging post-Cold War world. One was Francis Fukuyama's optimistic account of the "end of history" and the emergence of a peaceful and prosperous era driven by the triumph of economic and political liberalism. Another was Samuel Huntington's famous "Clash of Civilizations" thesis, which from the influential pages of Foreign Affairs - the leading journal among American foreign policy elites published by the Council on Foreign Relations (CFR), America's preeminent think tank on international politics - offered a rather different vision of world politics to come.

Huntington's reference to civilizations, which he largely defined around religious identity and history, did more than just offer an alternative narrative to liberal cosmopolitan optimism. At a time when many states appeared mired in domestic conflicts along ethnic-religious lines and Islamist movements were spreading across and beyond the Middle East, it abruptly brought, at the center of both scholarly and foreign policy, attention to a number of distinct but often intimately related discussions about the role and place of religion in international affairs.

\subsection{Religion matters}

Huntington indirectly brought attention to the vastly unexplored and seemingly growing relevance of cultural and religious forces in international politics. Indeed, not incidentally, the $1990 \mathrm{~s}$ saw the publication of a number of sociological works that directly challenged the secularization thesis and highlighted the continued, if not expanding, public vibrancy of religions and religious movements in America and around the world. The first volumes of the monumental Fundamentalism Project, edited by Martin Marty and Scott Appleby, were making their appearance in the scholarly world at this time. ${ }^{15}$ Sociologists of religion such as José Casanova were deeply challenging the privatization thesis embedded in secularization theories. ${ }^{16}$

What quite vigorously caught the attention of scholars and policy researchers at the time, in particular, was Peter Berger's recanting of the secularization

15 Martin E. Marty and R. Scott Appleby, The Fundamentalism Project, 5 vols. (Chicago: University of Chicago Press, 1991).

16 José Casanova, Public Religions in the Modern World (Chicago, IL: University of Chicago Press, 1994). 
thesis that he had done much to advance in the 1960 s-70 s. ${ }^{17}$ In 1999 , Peter Berger published an edited book suggestively titled The Desecularization of the World: Resurgent Religion and World Politics, ${ }^{18}$ under the auspices of the Ethics and Public Policy Center (EPPC), a Washington-based think tank with a conservative and religious bent. ${ }^{19}$ In the volume, Berger famously argued:

[...] the assumption that we live in a secularized world is false. The world today, with some exceptions [...] is as furiously religious as it ever was, and in some places more so than ever. This means that a whole body of literature by historians and social scientists loosely labeled "secularization theory" is essentially mistaken. ${ }^{20}$

\subsection{Religion, conflict and peace}

Huntington's piece also tapped into conventional understandings of the power of religions, in his case religion as an exclusive identity marker, in structuring and causing political conflict. Unlike much literature at the time that tended to see cultural forces as epiphenomenal, Huntington brought religion center stage in inter-state and inter-human relations. The concern for religion as a force for violence was mirrored by other research highlighting instead its possible contributions to peace.

Around the time of Huntington's Foreign Affairs article, Douglas Johnston was working on the Religion and Conflict Resolution Project at the Center for Strategic \& International Studies (CSIS), a Washington-based think tank. The project, which Johnston has described as "a complete novelty for a think tank devoted to hardnosed strategic issues and known for its realist Cold War mentality,"21 culminated in the 1994 co-edited volume with Cynthia Sampson, Religion: the Missing Dimension of Statecraft. The volume, forwarded by the former president Jimmy Carter and produced under the auspices of a major security-based

17 Peter L. Berger, The Sacred Canopy: Elements of a Sociological Theory of Religion (New York, NY: Anchor Books, 1969).

18 Berger, The Desecularization of the World: Resurgent Religion and World Politics. (Grand Rapids, MI: Ethics and Public Policy Center, Eermans Publishing, 1999).

19 The EPPC was established in 1976 to "clarify and reinforce the bond between the JudeoChristian moral tradition and the public debate over domestic and foreign policy issues." It is a think tank that brings together conservative Catholic, Evangelical, and Jewish intellectuals and analysts and straddles between secular and religious research. See http://www.eppc.org/ about/

20 Berger, The Desecularization of the World: Resurgent Religion and World Politics, 2.

21 Douglas M. Johnston, 10 June, 2011, interview with the author. 
think tank, was one of the first and most prominent pieces of research intended to speak to a broader policy audience about the nexus between religion, violence, and peace-building.

Johnston and Sampson's intent was to push for an intellectual paradigm shift by exposing both the epistemic and ideological secularist bias of the foreign policy and diplomatic establishment. Articles throughout the volume complained that in a world increasingly abuzz with religious fervor, the intellectual traditions and statecraft practices that American diplomats and policy-makers were steeped in were stubbornly secularist. American statecraft suffered from an "enlightenment prejudice," some suggested, ${ }^{22}$ or "dogmatic secularism," others lamented. ${ }^{23}$ This secularist bias, the book argued, was problematic for two reasons. First, it led scholars, policymakers and diplomats to discount the growing salience of religion in international affairs. Secondly, if religion was to be brought back into the study and praxis of international diplomacy, it should not be seen solely as a cause of conflicts, but also as a way to foster nonviolent change, and preventing or resolving conflicts.

Upon leaving CSIS, Johnston founded the International Center for Religion and Diplomacy (ICRD) in 1999. This was an important turning point for the deeply secularized foreign policy institutional and intellectual landscape in Washington. The ICRD was the first and most prominent faith-based "think and do tank" entirely dedicated to conducting programs and research at the nexus between religion and conflict around the world. ICRD was mainly created to practice what Johnston had preached in his edited volume The Missing Dimension. That is, "prevent and resolve identity-based conflicts that exceed the reach of traditional diplomacy by incorporating religion as part of the solution." 24 Since 1999, Johnston and ICRD have been at the forefront of debates about the necessity of integrating faith-based approaches to conflict resolution in American statecraft and diplomatic practices.

A further seminal work on religion, conflict, and peace published in this decade was Scott Appleby's The Ambivalence of the Sacred. ${ }^{25}$ The book was an out-

22 Edward Luttwak, “The Missing Dimension," Religion, the Missing Dimension of Statecraft, eds. Douglas M. Johnston and Cynthia Sampson (New York, NY: Oxford University Press, 1994), 9.

23 Stanton Burnett, "Implications for the Foreign Policy Community " Religion, the Missing Dimension of Statecraft, ed. Douglas M. Johnston and Cynthia Sampson (New York, NY: Oxford University Press, 1994), 286.

24 http://icrd.org/.

25 R. Scott Appleby, The Ambivalence of the Sacred: Religion, Violence, and Reconciliation (Lanham, MD: Rowman \& Littlefield Publishers, 2000). 
growth of a project at the Kroc Institute for International Peace of the University of Notre Dame, funded in part by The Carnegie Commission on Preventing Deadly Conflict, concerned with bringing greater attention to religion and human rights and to emerging theories of religious peace building. The Kroc Institute was founded in 1986 out of a deep concern for nuclear weapons and the arms race. Here, in 2000, thanks to Scott Appleby, a Program on Religion, Conflict and Peacebuilding was then launched.

\subsection{International religious freedom}

Echoing Huntington's theme of civilizational clashes, Michael Horowitz, a senior fellow at the Hudson Institute, a conservative think tank in Washington DC, published in 1995 an editorial in The Wall Street Journal entitled, "New Intolerance Between the Crescent and the Cross.” The inflammatory article was responsible for putting the issue of alleged mounting Christian persecution in Muslim-majority countries on the map. As the campaign against Christian persecution gathered momentum, vigorously pushed forward also by Nina Shea and Paul Marshall of the Center for Religious Freedom at Freedom House, a Washingtonbased research and advocacy institute, it produced the Congressional initiatives which ultimately led to the passage of the International Religious Freedom Act (IRAF) in $1998 .^{26}$

IRFA led to the institutionalization of religious freedom as an instrument of American foreign policy. This policy change increased the profile and importance of international religious persecution and freedom among American foreign affairs experts. When Robert Seiple, first-ever U.S. Ambassador-at-Large for International Religious Freedom in the State Department (between 1998-2000), left his post, he founded another key institution in the faith-based "think and do tank" DC panorama, the Institute for Global Engagement (IGE).

Since 2000, IGE, which has been directed by Robert's son Chris Seiple, has pursued two important and parallel missions. First, it has directly worked for the promotion of international religious freedom through programs and initiatives on the ground. Second, it has sought to become a leading intellectual force at the intersection of American scholarly and policy debates on religion and reli-

26 For different perspectives on the motivations animating the anti-persecution and religious freedom campaign, see Allen D. Hertzke, Freeing God's Children: the Unlikely Alliance for Global Human Rights (Oxford: Rowman \& Littlefield Publishers, 2004); T. Jeremy Gunn, "The United States and the Promotion of Freedom of Religion and Belief," in Facilitating Freedom of Religious Belief: A Deskbook, ed. Tore Lindholm, et al. (The Hague: Martinus Nijhoff, 2004). 
gious freedom in international affairs. IGE's contribution to these debates and to American foreign policy will be touched upon in greater detail in the following section.

In sum, with the end of the Cold War, religion appeared to command a sporadic but growing attention among leading scholars in the social sciences and among certain areas of the Washington-based think tank and policy advocacy community. Huntington's Foreign Affairs article brought public attention to a range of issues as they pertained to the intersection of religion and international affairs. ${ }^{27}$ Security-based think tanks such as the CSIS, more generalist ones such as the Hudson Institute and Freedom House, faith-based ones such as the long-established EPPC and the newly created ICRD and IGE, along with Notre Dame's Kroc Institute, were all giving greater attention to the matter. These developments anticipated many of the issues and themes - from an interest in understanding global religious dynamics, to faith-based approaches to conflict-resolution, and international religious freedom - that would then be picked up, expanded and carried forward by an increasing number of scholarly and policy research projects and initiatives in the post-9/11 world.

\section{2001-2014: The Expansion and Consolidation of Post-secular Expertise}

The public religiosity of President Bush, the attacks on September 11, 2001 carried out by Al Qaeda, an organization that based its political legitimacy and worldview on a radical interpretation of Islam, and the religiously charged discourses that surrounded America's War on Terror thereafter, have had a dramatic effect in spurring greater attention to religion in American scholarly circles and foreign policy debates. Post-secular expertise expanded considerably, progressively consolidating in both secular and religious-based universities, secular and newly created faith-based think tanks, and other research centers. This development occurred along the intellectual tracks already laid out in the previous decade.

27 A fourth area where Huntington's article was seminal was in directing foreign policy attention towards Islam. This spurred important debates about the possibilities of clashes or dialogue with the Muslim world in the post-Cold War era. For reasons of space, this article focuses mostly on the issue of religion more generally and not Islam in particular. For a more detailed account of American post-secular expertise on Islam and foreign policy change, see Gregorio Bettiza, "The Social and Material Construction of Civilizations in International Relations: the "Muslim World'in American Foreign Policy after 9/11 “ (Florence: Max Weber Working Paper, 2013). 


\subsection{Religion matters}

Universities, often thought of as the bedrock institutions of secularism in America, started to open centers and offer new courses, discussing the complex and apparently ever growing salience of religion in international politics. This section does not present a comprehensive list of all new courses and developments across the American academy. ${ }^{28}$ It will focus on a number of changes in leading scholarly institutions, especially those with important links to the Washington foreign policy community.

A key development in post-secular expertise in the academic panorama has been the inauguration in 2006 of the Berkley Center for Religion, Peace and World Affairs, at Georgetown University in Washington DC. ${ }^{29}$ Georgetown has long been recognized as a leading training ground for America's security experts, diplomats, and foreign policy decision-makers. The Berkley Center has been organized around an ever-expanding number of programs that carry out research, organize conferences, and design university courses on religion in international affairs. As of 2014, the center featured such programs as Globalization, Religions, and the Secular, led by José Casanova; Religion and US Foreign Policy, led by Thomas Farr; the Religious Freedom Project, led by Thomas Farr and Timothy Samuel Shah; Religion, Conflict, and Peace led, by Eric Patterson; and Islam and World Politics, led by Jocelyne Cesari.

I will touch upon some of these programs in greater detail in a moment. What is interesting to note, at this stage, is that much of this wealth of knowledge produced by prominent scholars in the fields of sociology of religion, religion in comparative and international politics, and Islam in world politics, filters into policy-making through two important channels. First, through teaching and in particular thanks to an optional certificate course in Religion, Ethics, and World Affairs, available to interested students, launched by the Berkley Center in 2011 in collaboration with Georgetown University's Edmund A. Walsh School of Foreign Service. Second, through a wide-ranging series of scholarly publications, courses, events, and seminars explicitly targeted not just to scholars but also to foreign policy and security officials in the State Department and the military. ${ }^{30}$

The Notre Dame Kroc Institute's Religion, Conflict and Peacebuilding program, under the direction of Scott Appleby, has continued to be a key center

28 For a good overview of courses in the United States see: http://globalengage.org/global-ed ucation/syllabi. Accessed October 14, 2014.

29 berkleycenter.georgetown.edu .

$30 \mathrm{http} / / /$ berkleycenter.georgetown.edu/publications and berkleycenter.georgetown.edu/events 
in the production of social scientific, as well as theological, ${ }^{31}$ knowledge on religion and peace. Daniel Philpott, one of the leading and most prominent voices in the burgeoning field of religion in comparative politics and international relations, has long been associated with the Kroc Institute.

Other major universities, with a more secular tradition than Catholic Georgetown and Notre Dame, have launched important projects. The Belfer Center, Harvard University's Center for international affairs, hosted between 2007-2012 the Initiative on Religion in International Affairs directed by Monica Duffy Toft, one of the foremost scholars of religion and conflict. Courses, seminars, executive training sessions, and research projects were offered, "focusing on the study of religion as it bears on international relations and foreign policy," 32 with the goal to "integrate a sophisticated understanding of religion with international affairs in policymaking and scholarship."

Johns Hopkins' School for Advanced International Studies (SAIS), in the heart of Washington DC, labeled its 2009-10 academic year the Year of Religion, and hosted a wide range of seminars, workshops and events on the topic. ${ }^{34} \mathrm{~A}$ Global Politics and Religion Initiative was then launched in 2012 designed to help incorporate the study of religion and politics into the school's existing graduate-level international relations program; to promote new Master's degree courses, faculty and community research seminars; and to provide executive education training sessions. The initiative's goal is to "foster an appreciation and deeper understanding of religion and international affairs among students, scholars and practitioners who will shape and influence future policymaking." 35

In terms of the academic environment, a further noteworthy development was the inauguration in 2007 of The Immanent Frame blog, sponsored by the Social Science and Research Council. The blog has been at the forefront of scholarly debates on religion and the secular in the humanities and the social sciences, hosting contributions by prominent social theorists and philosophers in the field. ${ }^{36}$ The blog has also served as an important venue for a number of debates

31 http://kroc.nd.edu/research/religion-conflict-peacebuilding/theology-practice-just-peace

32 http://belfercenter.ksg.harvard.edu/project/57/religion_in_international_affairs.html?page_ id $=159$

33 http://belfercenter.ksg.harvard.edu/project/57/religion_in_international_affairs.html?page_ id $=159$

34 www.sais-jhu.edu/religion/index.htm

35 www.sais-jhu.edu/academics/functional-studies/global-theory-history/global-politics-andreligion-initiative.html

36 The blog, edited by Jonathan VanAntwerpen, has published contributions by Charles Taylor, Jürgen Habermas, Talal Asad, Robert Bellah, Craig Calhoun, José Casanova, William E. Connolly, Mark Juergensmeyer, and Saba Mahmood, among others. 
about the growing operationalization of religion in American foreign policy, whether religious engagement and faith-based approaches to conflict resolution, or religious freedom. ${ }^{37}$ While some, such as Elizabeth Shakman Hurd or Winnifred Fallers Sullivan, have tended to be critical, these developments have nevertheless contributed to substantially raise the stakes as well as attention around the growing nexus between religion and US foreign policy, far beyond the immediate circle of its most engaged advocates.

Interest in understanding religion, how it relates to international affairs and American foreign policy, has not been the concern of academics and universities alone. Policy-makers and think tanks are also increasingly turning their gaze towards God. That the intellectual mood among policy elites was increasingly changing became especially evident when the former-Secretary of State Madeleine Albright published her autobiographical reflections on how the "Mighty and the Almighty" had become surprisingly relevant to international relations and America's security at the dawn of the twenty-first century. ${ }^{38}$ In her memoirs, Mrs. Albright argued that in order "to anticipate events rather than merely respond to them, American diplomats will need to [...] think more expansively about the role of religion in foreign policy and about their own need for expertise."39

The Council on Foreign Relations (CFR) has wholly embraced and partly led this post-secular turn within the policy community. From 2003 to 2006, CFR launched a Religion and U.S. Foreign Policy Project - designed to address "one of the most important challenges facing U.S. foreign policy in the 21st century: the growing importance of religion in world politics"40 - led by Walter Russell Mead, a historian and scholar of American foreign policy, and Timothy Samuel Shah, a political scientist. During this period, CFR became active in engaging the evangelical community and its leaders, such as Richard Land of the Southern Baptist Convention, and Rick Warren pastor of Saddleback Church. ${ }^{41}$ Mead's seminal article “God's Country?,” which appeared in 2006

37 http://blogs.ssrc.org/tif/2013/07/30/engaging-religion-at-the-department-of-state/ and http://blogs.ssrc.org/tif/the-politics-of-religious-freedom/

38 Madeleine K. Albright, The Mighty and the Almighty: Reflections on America, God, and World Affairs, Large print ed. (New York, NY: Harper Large Print, 2006).

39 Madeleine K. Albright, The Mighty and the Almighty: Reflections on America, God, and World Affairs, 99.

40 http://www.cfr.org/projects/religion-and-politics/religion-and-us-foreign-policy-project/ pr421

41 http://www.cfr.org/projects/world/evangelicals-and-foreign-policy-roundtable/pr1287; http://www.cfr.org/religion-and-politics/christian-evangelicals-us-foreign-policy/p11341 
on the pages of Foreign Affairs and charted the growth and influence of Evangelicals in American foreign policy, grew out of these initiatives.

Following this early and specific interest on Evangelicals, CFR then established in 2006 a broader Religion and Foreign Policy Initiative. Its stated scope is to provide a more structured "forum to deepen the understanding of issues at the nexus of religion and U.S. foreign policy." The initiative does so by collecting research, hosting conferences, and organizing events as a way to connect and serve as a resource for religious and congregational leaders, scholars, and thinkers on religion "whose voices are increasingly important to the national foreign policy debate." ${ }^{42}$ A Religious Advisory Committee provides guidance for all aspects of the initiative. Along with boasting the presence of Madeleine Albright, it includes many of the most prominent American scholars and analysts on religion, as well as religious leaders across groups and denominations. ${ }^{43}$

A number of leading Washington-based think tanks covering both domestic and foreign affairs are also paying increasing attention to religion. Since the early $2000 \mathrm{~s}$, the Brookings Institute moved slowly beyond exploring the intersection of religion in domestic politics, widening its interest toward international affairs. In 2003, it organized a prominent conference on religion and American foreign policy, which led to an edited volume Liberty and Power: A Dialogue on Religion and U.S. Foreign Policy in an Unjust World. Through the work of scholars and fellows - such as E.J. Dionne on religion in America, Justin Vaisse on Islam and Europe, and Ömer Taşpinar on religion and secularism in Turkey and the Middle East - Brooking's engagement with religious actors and issues has expanded considerably over the past decade.

The AEI has hosted discussions and commentary by Michael Novak and others on religion and American politics since the 1980 s. Their frequency, however, noticeably increased during the $1990 \mathrm{~s}$, as a quick glance at AEI's webpages reveals. ${ }^{44}$ Following 2001, a growing attention was directed towards international

42 http://www.cfr.org/about/outreach/religioninitiative/mission.html

43 Among scholars and analysts, the committee includes Peter Berger, Boston University; Father Bryan Hehir, Harvard University; Scott Appleby, University of Notre Dame; Reza Aslan, University of California Riverside; Mark Noll, University of Notre Dame; Luis Lugo, Pew Forum on Religion and Public Life; and Paul Marshall, Hudson Institute. It counts among its religious leaders and activists the following: Richard Land, Southern Baptist Convention; Eboo Patel, Interfaith Youth Core; Feisal Abdul Rauf, Cordoba Initiative; David Saperstein, Religious Action Center of Reform Judaism; Chris Seiple, Institute for Global Engagement; Richard Stearns, World Vision; Jim Wallis, Sojourners; and Robert Wood, The Church of Jesus Christ of LatterDay Saints. For the full list see www.cfr.org/about/outreach/religioninitiative/advisory_board. html

44 www.aei.org/policy/society-and-culture/religion/ 
issues with a focus on the religious character of America and Middle Eastern politics, in particular with reference to Israel and political Islam.

An important post-secular development in the secularized intellectual and policy milieu of Washington DC was the creation of the well-funded Pew Forum on Religion \& Public Life in 2001. ${ }^{45}$ The PEW Forum on Religion is one of the largest of seven projects that make up the Pew Research Center, a non-partisan research and polling institute. The Forum started as a place for bringing religious leaders across traditions - mainly Christians, Muslims and Jews - to engage in dialogue and interfaith discussions in the tense post-9/11 atmosphere. When Louis Lugo joined as director in 2004, he turned the forum into a research center that, as the website states, seeks to "promote a deeper understanding of issues at the intersection of religion and public affairs." It does so through two main programs, one on Religion and American Society, and the other on Religion and World Affairs.

The following statement by Louis Lugo, explaining the rational for re-directing the PEW Forum towards a research center on religion, captures perfectly the sentiment of many in the post-secular epistemic community:

When I took my Ph.D. in political science at the University of Chicago most social scientific theories I was taught assumed the world to be secularizing. But already since the late $1970 \mathrm{~s}$ with the Iranian revolution and Likud winning its first election in Israel I realized then that some kind of religious resurgence was occurring in the world... Peter Berger's admission that he was wrong about secularization in the $1990 \mathrm{~s}$ was another turning point. Things were happening, religion was everywhere, but no one was noticing. With the Forum we attempted to fill that knowledge vacuum with solid social scientific research. ${ }^{46}$

Seiple's IGE and Johnston's ICRD faith-based "think and do tanks" have become important fulcrums of research and debates on religion in international affairs. IGE's Center on Faith and International Affairs hosts a thriving research program that seeks to equip "scholars, practitioners, policymakers, and students with a balanced understanding of the role of religion in public life worldwide." ${ }^{47}$ The Center has been involved in supporting and publishing a series of scholarly and policy-oriented books on the nexus between religion, security, and international affairs, ${ }^{48}$ featuring most recently and prominently a volume co-edited by IGE's Dennis Hoover and ICRD's Douglas Johnston entitled Religion and Foreign

45 www.pewforum.org/

46 Louis Lugo, 24 June, 2010, interview with author.

47 www.globalengage.org/research/about.html

$48 \mathrm{http} / / /$ globalengage.org/faith-international-affairs/books 
Affairs: Essential Readings. ${ }^{49}$ Since 2002, IGE publishes a quarterly journal, The Review of Faith \& International Affairs, which is, to this day, the only peer-reviewed scholarly journal entirely dedicated to issues of religion and world politics. ${ }^{50}$

\subsection{Religion, conflict and peace}

Research at the intersection of religion, violence and conflict-resolution has expanded exponentially within the academic field, as well as in the think tank community. A particularly prominent focus has been directed towards the issue of "religious engagement." Religious engagement is an umbrella term that encompasses two key concerns about American foreign policy voiced by post-secular intellectuals and experts: first, a critique of what is perceived to be an excessively secular approach to international affairs, which is blind to religious dynamics and conflicts; second, a call to understand religion and to include religious actors and factors more constituently in American diplomacy and conflict-resolution strategies.

Douglas Johnston and his ICRD have been at the forefront of these debates since the $1990 \mathrm{~s}$, and have continued to be throughout the $2000 \mathrm{s.}{ }^{51}$ A growing range of scholars, policy analysts, and religious activists have joined Johnston and his efforts to bring greater attention to religious engagement in American foreign policy. ${ }^{52}$

49 Dennis Hoover and Douglas Johnston, eds. Religion and Foreign Affairs: Essential Readings. (Waco, TX: Baylor University Press, 2012).The book collects a wide-range of seminal articles and excerpts in the field by Madeleine Albright, Scott Appleby, Benjamin Barber, Peter Berger, Timothy Byrnes, José Casanova, Thomas Farr, Jonathan Fox, Jeffrey Haynes, Allen Hertzke, Samuel Huntington, Mark Juergensmeyer, Paul Marshall, Vali Nasr, Daniel Philpott, Timothy Shah, Chris Seiple, and Scott Thomas, among others.

50 Since 2010, The Review is being published by Routledge/Taylor \& Francis, improving its scholarly quality and credibility, along with making it more widely available through the publisher's indexes.

51 Douglas M. Johnston, ed. Faith-based Diplomacy: Trumping Realpolitik (Oxford: Oxford University Press, 2003); Douglas M. Johnston, Religion, Terror, and Error: US Foreign Policy and the Challenge of Spiritual Engagement (Santa Barbara, California: Praeger Publishers, 2011).

52 The United States Institute of Peace (USIP) established a permanent Religion and Peacemaking Program in 2001. AT CSIS, religious-related initiatives are less well institutionalized. In 2007, CSIS Post-Conflict Reconstruction Project hosted a series of events on religion in conflict settings and produced a groundbreaking 92-page report entitled Mixed Blessings: U.S. Government Engagement with Religion in Conflict-Prone Settings (Washington D.C.: Center for Interna- 
Most prominent is the 2010 report on Engaging Religious Communities Abroad: A New Imperative for U.S. Foreign Policy by the Chicago Council on Global Affairs, explicitly addressed to the Obama administration. ${ }^{53}$ The report argued that "despite a world abuzz with religious fervor [...] the U.S. government has been slow to respond effectively to situations where religion plays a global role." ${ }^{54}$ It urged President Obama and his national security staff to make religion and engaging with religious communities around the world "an integral part of our [American] foreign policy." 55

The document was the result of a task force of thirty-two "experts and stakeholders" - former government officials, religious leaders, heads of international organizations, and scholars. The task force was co-chaired by Scott Appleby and Richard Cizik, president of the New Evangelical Partnership for the Common Good and former Vice President for Governmental Affairs of the National Association of Evangelicals (NAE). Key scholars and policy analysts directly or indirectly affiliated with Georgetown's Berkley Center were included in the task force, including José Casanova, Thomas F. Farr, Timothy Samuel Shah, Katherine Marshall, and William Inboden. Douglas Johnston was also a member, along with a number of prominent Muslim scholars and activists, such as Radwan A. Masmoudi, Dalia Mogahed, and Eboo Patel.

It is within this intellectual context that a Religion and Foreign Policy Working Group was convened in the State Department as part of its wider Strategic Dialogue with Civil Society initiative launched in 2011 to elevate and strengthen the U.S. Government's engagement with and support of a wide range of civil society actors. The Religion and Foreign Policy working group was tasked with making recommendations on four issues: Religion in Foreign Policy and National Security, Religious Engagement and Conflict Prevention/Mitigation, International Religious Freedom: Advocacy to Combat Religious-Based Violence and Human Rights Abuse, and Faith-Based Groups and Development and Humanitarian Assistance. Chris Seiple of IGE was invited to be one of the two civil-soci-

tional and Strategic Studies, 2007). The report extensively surveyed - with the intention to improve - US government attention and approaches to religion abroad.

53 Chicago Council, "Engaging Religious Communities Abroad: A New Imperative for U.S. Foreign Policy," in Report of the Task Force on Religion and the Making of U.S. Foreign Policy (Chicago: Chicago Council on Global Affairs, 2010). The report was covered by major media outlets and further generated a lively and sometimes heated debate within the social scientific community in the pages of The Immanent Frame. See blogs.ssrc.org/tif/category/religious-freedom 54 Chicago Council, "Engaging Religious Communities Abroad: A New Imperative for U.S. Foreign Policy," .21

55 . Chicago Council, "Engaging Religious Communities Abroad: A New Imperative for U.S. Foreign Policy," 13 
ety, non-governmental representatives of the working group. Following on the working group's recommendations in $2012,{ }^{56}$ Secretary of State John Kerry created an Office of Faith-Based Community Initiatives in 2013. ${ }^{57}$

\subsection{International religious freedom}

International religious freedom has become a major preoccupation of the American post-secular epistemic community. Research and advocacy efforts on this issue have continued and expanded in the think tank community since 2001. Nina Shea and Paul Marshall moved the Centre for Religious Freedom from Freedom House to the Hudson Institute in 2001. ${ }^{58}$ Chris Seiple of IGE went on to cofound the International Religious Freedom (IRF) Roundtable, a Washington-area consortium of NGOs concerned with the issue of religious freedom. The roundtable meets bi-monthly to discuss how best to promote religious freedom in American foreign policy, Washington policy circles, and across countries worldwide. ${ }^{59}$

These efforts are joined by greater scholarly attention to the historical roots, normative and philosophical substance, as well as strategic security imperatives of religious freedom as foundational to promoting democratic practices, fighting religious fundamentalism, fostering peace, and supporting economic development in societies around the world. Leading this scholarly effort has been Thomas Farr at Georgetown's Berkley Center, who has written about religious freedom on leading policy-oriented journals, such as Foreign Affairs and Foreign Policy. ${ }^{60}$ Since 2011, Farr also directs, along with Timothy Samuel Shah, the Berkley Center's Religious Freedom Project. The Project counts among its associates scholars and prominent academics on religion in the social sciences, including José Casanova, William Inboden, Daniel Philpott, and Monica Duffy Toft. ${ }^{61}$

An important source of social scientific research on religious freedom are the reports on Global Restrictions of Religion compiled by Brian Grimm at the PEW

56 IGE, "Inaugural Meeting of State Department Working Group on Religion and Foreign Policy,” Institute for Global Engagement (IGE), http://www.globalengage.org/pressroom/releases/ 1236-video-now-available-from-the-working-group-on-religion-and-foreign-policy.html.

57 http://www.state.gov/s/fbci/\#

58 http://crf.hudson.org/

59 www.aicongress.org/wp-content/uploads/2012/05/IRF-Roundtable-Web-Update.pdf.

60 Thomas F. Farr, "Diplomacy in an Age of Faith: Religious Freedom and National Security," Foreign Affairs 87, no. 2 (2008); Thomas F. Farr, "Undefender of the Faith," http://www.for eignpolicy.com/articles/2010/04/05/undefender_of_the_faith.

61 See: berkleycenter.georgetown.edu/rfp 
Forum on Religion. ${ }^{62}$ The PEW reports have provided a vast array of empirical data and statistics that scholars, campaigners and interested policymakers have widely and regularly drawn upon in their research and advocacy efforts. Grimm has explored the relationship between religious freedom and violence in further scholarly publications with leading sociologists of religion, ${ }^{63}$ and recently founded the Religious Freedom and Business Foundation. ${ }^{64}$

Parts of the post-secular epistemic community concerned with religious freedom are closely affiliated with the implementation, consolidation and expansion of America's international religious freedom policy. Robert Seiple served as firstever U.S. Ambassador-at-Large for International Religious Freedom in the State Department (between 1998 to 2000). Thomas Farr served as first director of the State Department's Office of International Religious Freedom (19992003). Nina Shea served as Commissioner of the United States Commission on International Religious Freedom (mandated by the 1998 International Religious Freedom Act). Moreover, Farr, Shea, Paul Marshall, Timothy Samuel Shah, Chris Seiple, and Brian Grimm have all, in various occasions and capacities, testified before Congress on issues of international religious persecution and freedom in the past two decades.

In terms of foreign policy priorities and bureaucratic politics, while slowly gaining ground, religious freedom remains largely quarantined and marginalized within the State Department. ${ }^{65}$ Paradoxically, post-secular experts usually critical of this agenda, mostly associated with the Politics of Religious Freedom project based at the University of California, Berkeley and Northwestern University, are contributing to raising the issue's domestic and international profile. ${ }^{66}$ The power of American international religious freedom discourse and practices, these critiques suggest, can no longer be ignored and its problematic nature needs to be urgently addressed. This is a further way that the heterogeneous, pluralist, and internally divided American post-secular epistemic community on religion in international affairs contributes to put religion on the scholarly and policy agenda.

62 http://www.pewforum.org/category/publications/restrictions-on-religion/

63 Brian J. Grim and Roger Finke, The Price of Freedom Denied: Religious Persecution and Conflict in the Twenty-First Century (Cambridge: Cambridge University Press, 2010).

$64 \mathrm{http}: / /$ religiousfreedomandbusiness.org/

65 GAO, "International Religious Freedom Act: State Department and Commission Are Implementing Responsibilities but Need to Improve Interaction,” (Washington D.C.: United States Government Accountability Office (GAO), 2013).

$66 \mathrm{http}$ //politics-of-religious-freedom.berkeley.edu/ 


\section{Conclusion}

With the end of the Cold War, a noticeable but sporadic interest emerged among American scholarly and policy elites toward exploring the ways that religion appeared to "matter" in international affairs and, by fiat, also to American foreign policy. Critiques of the secularization theory - its role in the production of social scientific knowledge about international affairs, as well as its influence over how the foreign policy establishment approached the world - were being put forward at this time.

The events of 9/11 provided a second turning point in this process. From then on, both a qualitative and quantitative explosion of post-secular expertise occurred in terms of new centers, initiatives, programs, and courses within the secular and religious academic and policy research worlds. Much of it sought to explore or critique the complex and multiple facets at the nexus of religion and international affairs. Their central claim was that social scientists on the one hand, and American foreign policy makers on the other, should better understand and integrate religion as defined according to the pluralist views of this epistemic community. As a result, over the past twenty years, the Washington foreign policy establishment's institutional and intellectual milieu has undergone what can be conceptualized as a process of desecularization. ${ }^{67}$ Talking about religion is no longer taboo among intellectual and policy elites.

Some tentative links between the rise of this heterogeneous post-secular epistemic community on international affairs and specific changes in American foreign policy were provided. In particular, it appears that post-secular expertise has been tied to the creation of a Faith Based and Community Initiatives office in the State Department, as well as to the institutionalization, consolidation and expansion of international religious freedom policy. Much closer scrutiny of the causal relationship between the emergence of the post-secular epistemic community, with its contestation of secular knowledge and practices, and changes in American foreign policy is warranted. The opposite should also be investigated - to what extent has the desire to influence American foreign policy driven much scholarly research on religion in international affairs?

67 Vyacheslav Karpov, "Desecularization: A Conceptual Framework," Journal of Church and State 52.2 (2010). 


\section{Works Cited}

Adler, Emanuel, and Peter M. Haas. "Conclusion: Epistemic Communities, World Order, and the Creation of a Reflective Research Program.” International Organization 46.1 (1992): 367-90.

Albright, Madeleine K. The Mighty and the Almighty: Reflections on America, God, and World Affairs. Large print ed. New York, NY: Harper Large Print, 2006.

Appleby, Scott R. The Ambivalence of the Sacred: Religion, Violence, and Reconciliation. Lanham, MD: Rowman \& Littlefield Publishers, 2000.

Bacevich, Andrew, and Elizabeth Prodromou. "God Is Not Neutral: Religion and US Foreign Policy after 9/11." Orbis 48.1 (2004): 43-54.

Berger, Peter L., ed. The Desecularization of the World: Resurgent Religion and World Politics. Grand Rapids, MI: Ethics and Public Policy Center; Eermans Publishing, 1999.

Berger, Peter L., ed. The Sacred Canopy: Elements of a Sociological Theory of Religion. New York, NY: Anchor Books, 1969.

Bettiza, Gregorio. "The Social and Material Construction of Civilizations in International Relations: The 'Muslim World'in American Foreign Policy after 9/11." Florence: Max Weber Working Paper, 2013.

Burnett, Stanton. "Implications for the Foreign Policy Community." In Religion, the Missing Dimension of Statecraft, edited by Douglas M. Johnston and Cynthia Sampson. New York, NY: Oxford University Press, 1994.

Casanova, José. Public Religions in the Modern World. Chicago, IL: University of Chicago Press, 1994.

Checkel, Jeffrey T. "Ideas, Institutions, and the Gorbachev Foreign Policy Revolution." World Politics 45.2 (1993): 271-300.

Chicago Council. "Engaging Religious Communities Abroad: A New Imperative for U.S Foreign Policy." In Report of the Task Force on Religion and the Making of US Foreign Policy. Chicago: Chicago Council on Global Affairs, 2010.

CSIS. "Mixed Blessings: US Government Engagement with Religion in Conflict-Prone Settings." Washington D.C.: Center for International and Strategic Studies, 2007.

Eyal, Gil and Larissa Buchholz." From the Sociology of Intellectuals to the Sociology of Interventions." Annual Review of Sociology 36 (2010): 117-37.

Farr, Thomas F. "Diplomacy in an Age of Faith: Religious Freedom and National Security." Foreign Affairs 87. 2 (2008): 110-24.

Farr, Thomas F. “Undefender of the Faith.” http://www.foreignpolicy.com/articles/2010/04/ 05/undefender_of_the_faith.

Fukuyama, Francis. The End of History and the Last Man. New York, NY: Free Press, Maxwell Macmillan, 1992.

GAO. "International Religious Freedom Act: State Department and Commission Are Implementing Responsibilities but Need to Improve Interaction." Washington D.C.: United States Government Accountability Office, 2013.

Grim, Brian J. and Roger Finke. The Price of Freedom Denied: Religious Persecution and Conflict in the Twenty-First Century. Cambridge: Cambridge University Press, 2010.

Gunn, Jeremy T. "The United States and the Promotion of Freedom of Religion and Belief." In Facilitating Freedom of Religious Belief: A Deskbook, edited by Tore Lindholm, W. Cole 
Durham Jr. , Elizabeth A. Sewell and Bahia G. Tahzib-Lie. 617-42. The Hague: Martinus Nijhoff, 2004.

Guth, James L. "Religion and American Public Opinion: Foreign Policy Issues." In The Oxford Handbook of Religion and American Politics, edited by James L. Guth, Lyman A. Kellstedt and Corwin E. Smidt. 243-65. New York/Oxford: Oxford University Press, 2009.

Haas, Peter M. “Introduction: Epistemic Communities and International Policy Coordination." International Organization 46.1 (1992): 1-35.

Hertzke, Allen D. Freeing God's Children: The Unlikely Alliance for Global Human Rights. Oxford: Rowman \& Littlefield Publishers, 2004.

Hoffmann, Stanley. “An American Social Science: International Relations.” Daedalus 106.3 (1977): 41-60.

Hoover, Dennis, and Douglas Johnston, eds. Religion and Foreign Affairs: Essential Readings. Waco, TX: Baylor University Press, 2012.

Hoover, Dennis R., ed. Religion and American Exceptionalism. New York, NY: Routledge, 2014. Howorth, Jolyon. "Discourse, Ideas, and Epistemic Communities in European Security and Defence Policy." West European Politics 27.2 (2004): 211-34.

Huntington, Samuel P. “The Clash of Civilizations?" Foreign Affairs 72.3 (1993): $22-49$.

IGE. "Inaugural Meeting of State Department Working Group on Religion and Foreign Policy." Institute for Global Engagement (IGE), http://www.globalengage.org/pressroom/releases/ 1236-video-now-available-from-the-working-group-on-religion-and-foreign-policy.html.

Johnston, Douglas M., ed. Faith-Based Diplomacy: Trumping Realpolitik. Oxford: Oxford University Press, 2003.

Johnston, Douglas M., ed. 10 June, 2011 Interview.

Johnston, Douglas M., ed. Religion, Terror, and Error: US Foreign Policy and the Challenge of Spiritual Engagement. Santa Barbara, California: Praeger Publishers, 2011.

Johnston, Douglas M. and Cynthia Sampson, eds. Religion: The Missing Dimension of Statecraft. New York, NY: Oxford University Press, 1995.

Karpov, Vyacheslav. "Desecularization: A Conceptual Framework." Journal of Church and State 52, no. 2 (2010): $232-70$.

Lugo, Louis. 24 June, 2010. Interview.

Luttwak, Edward. "The Missing Dimension." In Religion, the Missing Dimension of Statecraft, edited by Douglas M. Johnston and Cynthia Sampson. New York, NY: Oxford University Press, 1994.

Marty, Martin E., and R. Scott Appleby. The Fundamentalism Project. 5 vols. Chicago: University of Chicago Press, 1991.

Mead, Walter Russell. “God's Country.” Foreign Affairs 85.5 (2006): 24-43.

Overview of Courses on Religion in International Polities in the US: See http://globalengage. org/global-education/syllabi. Accessed October 14, 2014.

Rock, Stephen R. Faith and Foreign Policy: The Views and Influence of U.S. Christians and Christian Organizations. New York, NY: Continuum International, 2011.

Sandal, Nukhet A. "Religious Actors as Epistemic Communities in Conflict Transformation: The Cases of South Africa and Northern Ireland." Review of International Studies 37.3 (2011): 929-49.

Schmalzbauer, John, and Kathleen Mahoney. "Religion and Knowledge in the Post-Secular Academy.” New York: SSRC Working Papers, 2012. 
Schmalzbauer, John, and Kathleen Mahoney. "American Scholars Return to Studying Religion." Contexts 7.1 (2008): $16-21$.

Smith, Christian. The Secular Revolution: Power, Interests, and Conflict in the Secularization of American Public Life. London: University of California Press, 2003.

Waever, Ole. "The Sociology of a Not So International Discipline: American and European Developments in International Relations." International Organization 52.4 (1998): $687-727$. 
